\title{
The Effect of Dolomite Liming on Ex-Waste Disposal as a Media for Growing Green Mustard
}

\author{
Farida Arinie Soelistianto \\ Student of Doctoral Program in Environmental Science, Interdisciplinary Postgraduate Program, Universitas Brawijaya Malang, \\ Jl. Major General. Haryono no .169 Malang, East Java, Indonesia. \\ ${ }^{1}$ Martono Dwi Atmadja, ${ }^{2}$ Yani Ratnawati \\ ${ }^{1,2}$ Malang State Polytechnic Lecturer, Jl. Soekarno Hatta no.09 Malang, East Java, Indonesia
}

\begin{abstract}
Temporary waste collection (TPS) is not carried out with proper management, causing environmental damage. Piles of garbage collected at TPS come from disposal of domestic waste. To handle waste, waste handling procedures must be carried out, namely 3P (collection, transportation and disposal). If handling is not carried out, the land where the TPS is located will experience damage to the ecosystem. According to PP. 18/2008 states that waste management mandates that for each type of waste management efforts are made to limit and reduce it, except for disasters. Soil from piles of garbage changes its natural environment. Chemical elements resulting from the decomposition of waste due to being buried for years produce leachate (waste water). Wastewater damages microorganisms in the soil, especially from inorganic waste. Soil chemical properties are determined by the pH level or what is known as soil acidity $(\mathrm{pH}<7)$. Soil acidity can be increased by liming the soil. Limestone can increase calcium in the soil so that it can restore soil fertility and normalize soil pH. Dolomite is one of the agricultural limestone which has material from mountain limestone and shells. Dolomite lime is used to increase the $\mathrm{pH}$ of acidic soils or soil $\mathrm{pH}<7$. The purpose of this study was to determine the stability of the former TPS with liming and its effect on mustard plants as phytoremediation. The results of observation and testing of used TPS liming treatment by applying variations of soil waste, dolomite lime, and husk charcoal. The treatments were divided into groups $\mathbf{P}_{\mathbf{0}}$ (control), $\mathbf{P}_{1}, \mathbf{P}_{2}, \mathbf{P}_{3}$ (sand without dolomite). The results showed that the soil $\mathrm{pH}$ ratio of 1: 2: $1\left(\mathrm{P}_{2}\right)$ reached a stability of 6.8 compared to other treatments. Meanwhile, from observations of green mustard plants, the highest average number of leaves was 16 on the $21 \mathrm{st}$ day, while the stem height was about $5.6 \mathrm{~cm}\left(\mathrm{P}_{2}\right)$. The average root length measured on the 21 st day was 12.5 cm $\left(P_{2}\right)$. The conclusion is that the higher the dolomite mixing ratio, the soil acidity quality of the waste becomes stable, but the effect on mustard plant growth is not optimal.
\end{abstract}

Keywords:- Lime-Dolomite, TPS, mustard greens, soil pH, soil acidity of waste.

\section{INTRODUCTION}

The increasing number of population in urban areas has added to the problem of the surrounding environment [1]. One of the problems faced by cities is the increasing burden of waste generated by residents. Garbage is the residual material that results from a process. This residual material requires storage and requires management so as not to damage the soil and its environment. Garbage collection places, also known as temporary garbage dumps (TPS). Population growth has narrowed the land for garbage disposal, so that TPS is getting closer to residential areas [2]. RI Law No. 18/2008 contains provisions regarding the waste management system in Indonesia. Household waste management is further regulated by Government Regulation Number 81 of 2012. This law explains how the awareness and coordination of the community, business world and government in waste management. Garbage disposed of in the environment is expected not to harm the living things around it [3].

The high cost waste management factor makes the cooperation between the government and the community producing waste less good. Big cities in Indonesia are only able to collect and dispose of $\pm 60 \%$ of all waste production [4]. The value of $\pm 60 \%$ is mostly handled and disposed of in a manner incompatible with waste managementWell. Garbage that has accumulated over the years decomposes both aerobically and anaerobically. The result of decomposition of waste causes seepage of wastewater (leachate) with the characteristics of organic, inorganic and microorganism content [5]. Soil becomes acidic because it has a high COD value so that the $\mathrm{pH}$ level is $<7$. The quality of used land for civil and agricultural lands must be tested by the Standard Penetration Test (SPT). This test is to determine the characteristics of the high soil bearing capacity of the decline caused by completely decomposed waste. Various methods are used to improve soil physiology, for example by mixing soil with husk ash, or chemically mixing soil with cement [6]. Soil stability treatment is expected to be able to support the load on it perfectly. In addition to, can increase layer hardness and reduce soil expansion and cavity shrinkage. One form of soil chemical stability improvement is by mixing lime [7]. 
The type of lime used for soil stability in agricultural land is carbonate lime, namely dolomite lime (CaMg (CO3) 2 ). Dolomite is lime carbonate (raw lime) without heating. The constituent materials are mountain limestone and seashells. Dolomite is widely used for agricultural land improvement because it reacts more slowly, is easy to obtain and does not cause residue [8].

Soil physical improvement by liming soil aims to make acid soils neutral at $\mathrm{pH}$ levels therein [17]. Acidic soil is caused by metallic (inorganic) elements in the soil material. These metal elements include Aluminum (Al), Manganese ( $\mathrm{Mn})$ and Iron $(\mathrm{Fe})$ which cannot be processed directly by soil microorganisms. For example, the high solubility impact of aluminum can poison plants because the important element phosphorus (P) in the soil will be bound by aluminum so that phosphorus is not absorbed by plants [9]. Phosphorus for plants acts as a builder of albumin, cell division for leaves and fruit and seeds. Therefore, acid liming soils can absorb the surface of $\mathrm{Al}$ $(\mathrm{OH}) 3$ and $\mathrm{Fe}(\mathrm{OH}) 3$ and soil $\mathrm{pH}$ ranges from $>7$.

The role of dolomite lime able to increase soil $\mathrm{pH}$ levels, zeolites, namely increased cation exchange capacity (CEC), hydrogel or soil ability to hold water. If the acid soil has returned to stability, the soil improvement quality test can use the phytoremediation method [10].Utilization of plants in the Brassicaceae family in the phytoremediation method can function as transfer, absorption, and reduction of toxic compounds mixed in the soil. The absorption mechanism of metal elements by plants can be through the roots with water or those that are hydrophobic are absorbed by the root surface. Metal translocation from the root to the root endodermis, metal or foreign compounds will follow transpiration to the upper part of the plant via the transport network [11].

This research carried out with the aim of testing the stability of dolomite mixing from soil samples from the former TPS area. Pengamtan with laboratory scale samples. The location of the TPS area in Merjosari Village, Malang City. Observation of the results of phytoremediation of acid soil $\mathrm{pH}$ to neutral soil by planting green mustard seeds as phytoremediation. The liming method on the sample soil begins without treatment by measuring the $\mathrm{pH}$ level and soil temperature. The growth of mustard greens was observed from the comparison of soil samples, dolomite lime and husk charcoal. The nature of dolomite lime can reduce soil acidity $(\mathrm{pH})$ so that it moves to increase by changing some of the $\mathrm{H}+$ into water [12].Soil processing for TPS waste is divided into several stages, namely, the soil taken by the sample is dried for 1 week before mixing with dolomite, the next step is the soil is matured so that the lime mixture with the soil material is mixed before being green. mustard seeds are planted. Acidity testing with a soil $\mathrm{pH}$ meter was observed after one week of soil preservation and it is expected to be stable at a $\mathrm{pH}>6$. Testing the quality of soil waste by increasing the soil $\mathrm{pH}$ level. Green mustard seeds are planted after the soil is $\mathrm{pH}$ stable. Furthermore, observations on mustard greens as phytoremediation with plant growth include counting the number of mustard leaves that grow, stem height and root length after the seeds grow until the 21 st day.

\section{RESEARCH METHODOLOGY}

\section{A. Time and Place of Research}

This research was conducted from March to May 2020 at the Faculty of Agriculture, Brawijaya University Malang. This research uses experimental research methods at laboratory scale. Soil sampling at the former TPS Merjosari Village, Malang City. Soil samples were taken from the conditions the land is native to the area, rotting litter and soil to cover rotting litter. Merjosari Kelurahan TPS waste management still uses an open dumping (OD) system, or garbage is piled up in one open location without any management.

The soil conditions of the TPS without cover cause the waste to be exposed to rainwater and cause a decomposition process in the form of leachate (lechate). Leachate mixes in the soil, reducing soil quality (soil becomes acidic). The application of dolomite lime is most effective in restoring acid soil stability. The land used by TPS is mixed with inorganic waste such as plastics, metals, batteries and so on. Liming the soil waste was carried out by application of dolomite based on the weight variation of the mixture composition [13]. Comparison of soil waste, dolomite lime and husk charcoal. In this study, observations were made on the number of leaves, stem height and root length.

\section{B. Tools and Materials}

The tools used in this study include plastic plates, plastic buckets, plant pots with a diameter of $25 \mathrm{~cm}$, small shovels, plastic ropes, plastic bags, soil filters, digital scales, rulers, soil $\mathrm{pH}$ meter, husk charcoal, sand, water. , dry. , mustard seeds. This research was conducted using a non-factorial experimental method by observing the mustard greens. Physiological response of mustard greens to various ratios of dolomite lime mixture with former TPS land from heterogeneous waste.

Treatment factors include, $\mathrm{P}_{0}$ as a treatment control only soil waste without other treatment, P1 soil waste treatment: dolomite: husk charcoal with a ratio (1: 1: 1), P2 soil waste treatment: dolomite: husk charcoal with a ratio (1: 2) ): 1), $\mathrm{P}_{3}$ tillage: sand: husk charcoal. Waste land is taken at the location of the garbage dump in Merjosari Village, Malang City. Soil sampling from the top layer (30$40 \mathrm{~cm})$ [14].

The initial treatment is drying the soil sample for 1 week. Dry waste soil is cleaned of the material in it, then filtered with a soil filter so that the soil sample is clean [15]. Clean soil is weighed for treatment, that is, each pot is filled with 500 grams of trash. Control pot only contains trash soil, while $\mathrm{P}_{1}$ contains 150 grams of waste soil: 150 grams of dolomite: 150 grams of husk charcoal, pot $\mathrm{P}_{2}$ contains 100 grams of waste soil: 200 grams of dolomite: 100 grams of husk charcoal, $\mathrm{P}_{3}$ contains 150 grams of soil manure: sand 150 grams: 150 grams of husk charcoal. 
The planting medium that has been prepared with a mixture of 4 ingredients, namely soil waste, dolomite lime, husk charcoal and sand. The soil mixture is put into a pot according to the type of treatment and left for three days under monitoring of $\mathrm{pH}$ and soil temperature before planting mustard seeds. On the 4th day of planting green mustard seeds, first the mustard seeds are immersed in clean water. Its function is to select seeds that are in good condition. The good seeds will sink in the water while the bad will float. A total of 25 mustard seeds were planted in each pot. The tillage process with dolomite liming as a growing medium does not add chemical fertilizers [18].This is to determine the stability of the cultivated soil against plant growth without other additives. Watering is given when the seeds are sown early, so that soil moisture is maintained.

\section{Research Flowchart}

This research was conducted according to the experimental stages on a laboratory scale in the order shown in Figure 1.

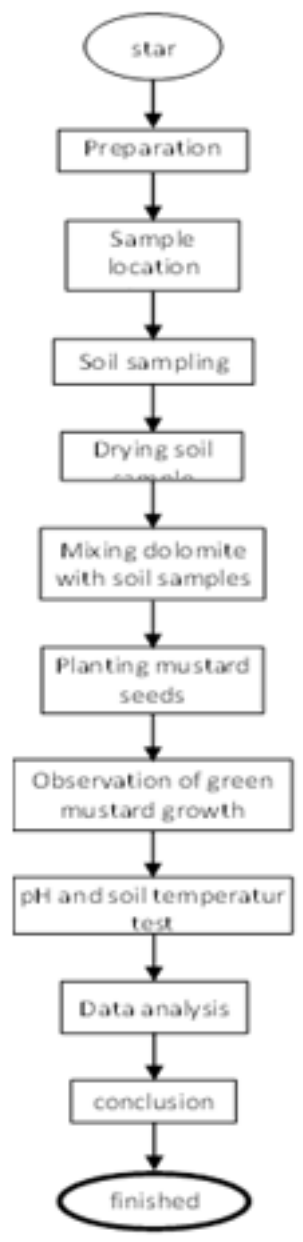

Fig 1:- Land TPS Repair and Phytoremediation

The sequence of the research process shows the treatment of the former TPS land sample, taken with a suitable tool to the surface of the soil $(30-40) \mathrm{cm}$. Preserving the soil after the sample is dried and filtered from the accompanying impurities. The growth of mustard greens as an accumulator plant was observed from the 3rd day of seed germination. Watering and measuring soil $\mathrm{pH}$ every day.

\section{ANALYSIS}

Based on the results of the research, it produces observation chart data with the following research stages:

The initial stage of processing the soil sample is dried and cleaned of mixed materials. Furthermore, the soil stability was mixed for 3 days with dolomite lime and husk charcoal. Treatment without dolomite used soil waste, husk charcoal and sand $\left(\mathrm{P}_{3}\right)$. The maximum total average of treatment media is between 450 - 500 grams. Furthermore, the green mustard seeds are sown in 4 planting pots. Soak the green mustard seeds before planting for 2 hours with clean water. Soak the mustard seeds to get good seeds [16].

Germination observations were carried out every day on the 3rd day the seeds grew in control pots $\left(\mathrm{P}_{0}\right)$ and $\mathrm{P}_{3}$ (mixed with sand). Soil $\mathrm{pH}$ test is carried out every day to determine the quality of soil acidity from dolomite processing. Watering is done every day to maintain soil moisture at a position of $70 \%-90 \%$ of the soil moisture content. Observation of growth power from the conditions of the day after planting mustard greens (HST) from the 3rd day to the 21 st day. Pengamtan from the number of leaves, shoot height, and root length were measured on the $21 \mathrm{st}$ day. Figure 2 results of the treatment of mustard seeds from their uniformity of growth.

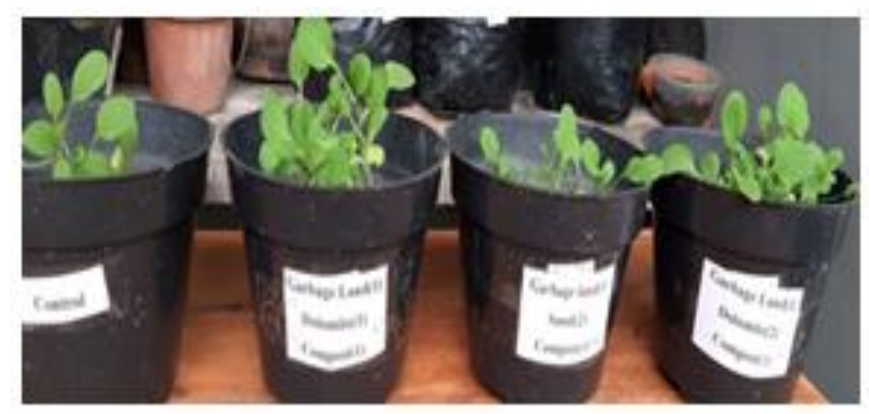

Fig 2:- Green Mustard Seed Growth

This study provides observational data when the mustard germinates start on the 3rd day. Simultaneous seed growth can be observed on the 7 th day. Soil $\mathrm{pH}$ level 5,2 increased on day -7 for $\mathrm{P}_{1}$. Moist soil conditions with a moisture content of about $80 \%-90 \%$.

\section{RESULTS}

From the research, data obtained from observations of green mustard plants with $\mathrm{pH}$ measurements on soil media and a constant temperature between $24^{\circ} \mathrm{C}-27^{\circ} \mathrm{C}$ as shown in Figure 3. Soil $\mathrm{pH}$ levels with liming quality increased to $\mathrm{P}_{2}$ with the ratio of soil waste, dolomite, and husk. charcoal (1: $2: 1)$. The reduced acid content was measured on the 7 th day with an average result of 6.8 . 


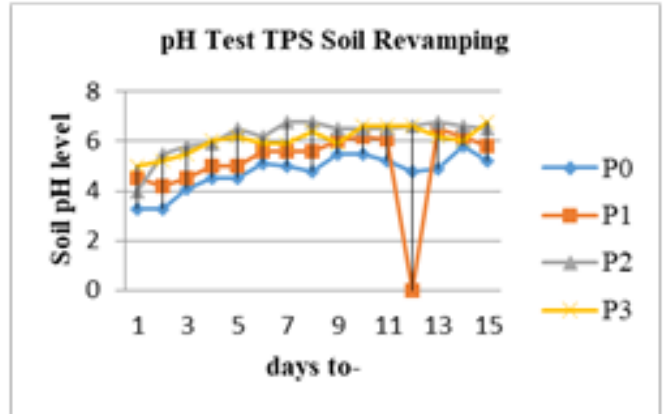

Fig 3:- Soil pH Level Graph

Dolomite liming on the TPS sample soil has not shown a maximum effect on phytoremediation of mustard plants. The results of the number of leaves and stem height for dolomite application were 1: 1: 1 (P1) and 1: 2: 1 (P2). Likewise without treatment on TPS soil mixed with fine sand, it's just that the growth of green mustard seeds was faster than the control during germination.

P3 germination is the growth of shoots and leaves faster than given dolomite lime. The mustard stems that were controlled also became stunted and the leaves were not fully developed.

The difference in new root growth can be observed on day 21 , namely $\mathrm{P} 0=5.5 \mathrm{~cm}, \mathrm{P} 1=8 \mathrm{~cm}, \mathrm{P} 2=12.5 \mathrm{~cm}, \mathrm{P} 3=$ $12 \mathrm{~cm}$. The results of root measurements show a significant difference between control and dolomite liming. The mixed sand in the used soil sample also raises further research because the effect on dolomite use is not much different. Figure 4 shows the average height of mustard greens measured from the ground to the tips of the leaves.

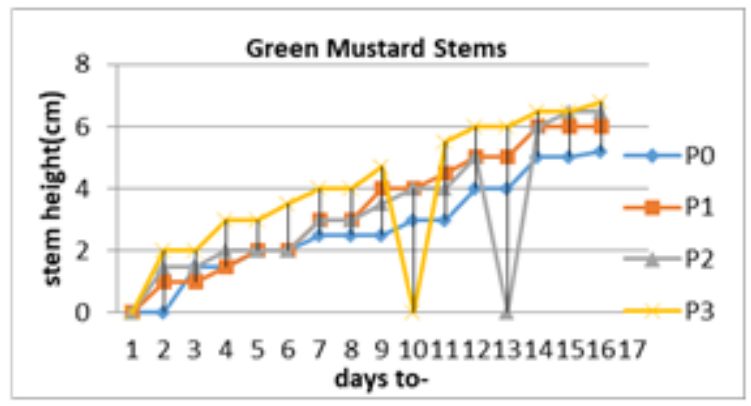

Fig 4:- Stem Height of Sawi Hijau

The height of the mustard plants measured since the day after planting (DAT) could not grow optimally. The acidic nature of TPS soil still has an effect, because nutrient absorption from the roots is inhibited [19]. It is possible that the metal content in the soil also affects the growth of mustard plants. While the average number of leaves was counted from the mustard shoots, on the 4th day the leaf sprouts began to grow 2 .

The highest number of leaves was 16 leaves on the 21 st day as in Figure 5 with the use of $\mathrm{P}_{2}$ dolomite lime. Dolomite was able to provide different quality results for the number of leaves compared without treatment (control).

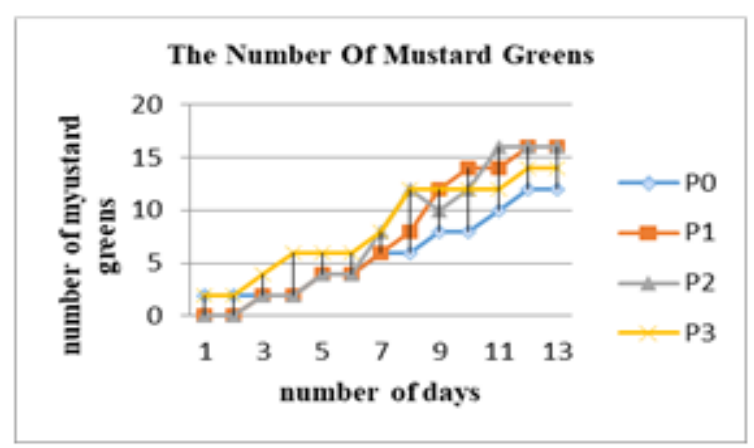

Fig 5:- Number of Green Mustard Leaves

This study did not use fertilizers so that the production of leaf number and plant height could not be maximized. Nutrients that tend to influence the development of mustard greens. With the acidity content of the remaining soil which slowly becomes stable after the dolomite liming process, the phytoremediation effect of mustard greens is also less than optimal. The average $\mathrm{pH}$ value is still below 7 .

\section{CONCLUSION}

Improvement of soil samples from TPS Kelurahan Merjosari, Kotamdaya Malang concluded that the soil acidity level was still high from the measured $\mathrm{pH}$ of about 4.5 before treatment. Green mustard as a phytoremediation plant above the ground showed a fairly stable growth but the difference between $\mathrm{P}_{1}$ and $\mathrm{P}_{2}$ was not visible. Stem height and number of leaves differ when observed from $\mathrm{P}_{0}$. Dolomite lime treatment had an average shoot length of 6.5 $\mathrm{cm}$, while the number of leaves was 18 sheet in $\mathrm{P}_{2}$. Green mustard root was observed on day 21 and tended not to develop well at $P_{1}$ and $P_{2}$ which were about $(12-12.5) \mathrm{cm}$ in length. Fertilization is not carried out on mustard plants so that only observations of soil $\mathrm{pH}$ suitability with dolomite can improve soil acidity conditions. Liming the soil at TPS Merjosari Village, Malang City with dolomite agricultural lime has a positive impact to help improve soil physical repair. Research can be continued by observing the metal elements contained in TPS soil.

\section{REFERENCES}

[1]. S. Tempuyak, C, Anwar, MH, Sangadji, "Analysis of Population Growth Projections and the Need for Solid Waste Facilities in Palu City 2015-2025," Journalist Catalog, vol.4 (4), p. 94-104, April 2016.

[2]. T. Armela, DS, Dermawati, M.Ischak., "The Influence of Settlement Conditions on Industrial Worker Housing Preferences in Kampung Tiban Settlements," AGORA Journal, vol. 15 (1), pp. 36-51, June 2015

[3]. M. Quina and A. Erou, "Application of Waste Management Law (HPSN 2019)," ICEL Journal, vol 1, p. February 1-6 2019.

[4]. Fangga, S. A, Mulasari, "Government Policy in Domestic Waste Management in Bantul Regency, DI Yogyakarta Province," Journal of Public Health, vol. 9 (2), pp. 1-15, September 2016.

[5]. VD, Pribadi, B.Iswanto, DI, Hendrawan, "Market Degradation of Organic Waste and TPA Using Anaerobic Reactors," Journal of Veterinary 
Engineering and Environmental Health, vol. 4, pp. 771-776, April 2018.

[6]. A. Rokhman, GP, Artiani, "Improvement of the Physical Properties of Ex-Piled Waste Using Lime Stabilizing Materials," FTUMJ Journal, vol. 3, p. 1-10 November 2015.

[7]. RI, Lesmana, Muhardi, SA, Nugroho, "High Plasticity Soil Stability with Cement," Journal of FTEKNIK, vol. 3 (2), p. 1-13, October 2016.

[8]. MR, Alibasyah, "Changes in Several Physical and Chemical Properties of Ultisols Due to Application of Dolomite and Lime Compost on Rice in Rice," Floratek Journal, vol. 11 (1), pp. 75-87, July 2016.

[9]. S.Hadi, E. Daningsih, Vokhebed, "Differences in Phosphorus Concentrations in Green Spinach Growth in Super Mini Hydroponics," Journal of JOM Faperta, vol.2 (1), p. 1-10, February 2015.

[10]. Nurlela, NE, Permata Sari, SE, Wardoyo, "Phytoremediation of Cd Heavy Metal Contaminated Soil Using Hanjuan Plants (Cordyline fruticosa)," IPA Journal of the University of Nusa Bangsa, vol. 9 (2), pp. 57-65, July 2019.

[11]. G. Junyo, E. Handayanto, "The Potential of Three Mustard Plant Varieties as Soil Mercury Accumulator," Journal of Soil and Land Resources, vol.4 (1), p. 421-429, June 2017.

[12]. YH, Lawing, "The Effect of Dolomite Lime on Gaharu Seed Growth in PT Tanito Harum Post Mining Land," Journal of Mining Geology, vol. 1 (23), pp. 31 42, February 2018.

[13]. D.Krisnawati, C. Bowo, "Application of Agricultural Lime to Increase Rice Production in Alluvial Rice," Agricultural Scientific Journal, vol. 2 (1), pp. 13-18, February 2019.

[14]. J.Suryono, K. Kusuma, Mulyadi, "Soil Sampling for Soil Fertility Research," Jurnal Balittanah, vol.2, pp. $1-15,2019$

[15]. M.Arifin, "Study of Physical Properties of Soil and Various Land Use in Relation to Estimates of Soil Erosion," Journal of MAPETA, vol.12 (2), p. 111-116, April 2010.

[16]. Inri, S.Paling, I. Alua, "Soaking Time of Green Mustard Seed (Brassica rapa var. Parachinensis) in Local Microorganism Solution (MoL) Kepok Banana Beetle (Musa paradisiaca L.) Against Seed Viability," Journal of Stigma, vol. 12 (1), p. 11-20, May 2019.

[17]. Subandi, A. Wijanarko, "The Effect of Lime Application Techniques on the Growth and Yield of Soybean in Acid Soil," Journal of Agriculture and Food, vol.32 (3), p. 171-178, September 2013.

[18]. L. Trakal, M. Neuberg, P. Tlutos, J, Szakova, V. Tejnecky, O.Drabek, "Application of Dolomite Limestone as Chemical Immobilization of Metal Contaminated Soil," Journal of Palnt Soil Environ, vol. 57 (4), pp. 173-179, 2011.

[19]. NA, Khan, M.Mobin, Samiullah, "The Effect of Gibberellic Acid and Sulfur Fertilization Levels on the Growth and Efficiency of Sawi (Brassica juncea) Use," Journal of Plants and Soil, vol. 270, p. 269-274, July 2005. 